\title{
PERENCANAAN SISTEM REDUCE, REUSE DAN RECYCLE PENGELOLAAN SAMPAH DI KAMPUS UNIVERSITAS ANDALAS LIMAU MANIS PADANG
}

\author{
Slamet Raharjo, Muhammad Zulfan, Taufiq Ihsan, Yenni Ruslinda \\ Jurusan Teknik Lingkungan Fakultas Teknik Universitas Andalas \\ Email: sraharjo@ft.unand.ac.id
}

\begin{abstract}
ABSTRAK
Pengelolaan sampah eksisting yang dilakukan pihak Unand masih menerapkan pola kumpul-angkutbuang. Pola tersebut tidak sesuai dengan Kebijakan dan Strategi Nasional Pengembangan Sistem Pengelolaan Persampahan. Oleh karena itu perlu dilakukan perencanaan sistem $3 R$. Perencanaan sistem dilakukan untuk 5 tahun (2014-2018) dengan target pelayanan sistem pewadahan dan pengangkutan sampah mencapai $100 \%$ dan tingkat pengolahan di Pusat Pengolahan Sampah Terpadu (PPST) mencapai 78,77\%. Sistem pewadahan dan pengumpulan sampah dilakukan dengan metode terpilah yang masing-masing dilakukan dengan pembedaan warna wadah sampah dan penjadwalan penjemputan sampah sesuai dengan pengelompokan jenis sampah. Adapun pengelompokan sampah dibedakan menjadi 3 yaitu sampah organik yang bisa dikompos seperti daundaunan dan sisa makanan, sampah yang bernilai jual seperti sampah kertas, botol dan gelas plastik, kaleng, dan berbagai logam dan sampah lain-lain yang akan dibuang ke TPA seperti kayu, rantingranting besar, kertas dan plastik yang tidak bisa dijual, dsb. Pengolahan sampah di PPST Unand terdiri dari proses pengomposan dan pencucian, pengepakan dan penjualan ke lapak/bandar sampah untuk sampah yang bernilai ekonomi. Sisa sampah yang tidak terolah sebanyak 21,23\% dibuang ke TPA Air Dingin. Program-program non teknis yang harus dilakukan diantaranya adalah pembentukan struktur organisasi yang khusus menangani persampahan dan penerbitan peraturan tentang kewajiban warga kampus dalam penanganan sampah secara $3 R$.
\end{abstract}

Kata kunci: Pengelolaan sampah, PPST Unand, Kompos, Daur Ulang, 3R

\begin{abstract}
Andalas University has been managing its solid waste by conventional method including collecting, transporting and dumping. The current management is not in accordance with the National Policy and Strategy Development of Solid Waste Management System. Therefore it is necessary to create a system that based on reduce, reuse and recycle idea. Development program is planned for 5 years (20142018) to achieve $100 \%$ in service and waste transportation and $78 \%$ in waste utilization. Sorting method is applied at temporary waste storage and collection system. Trash containers are distinguished by colour while trash pick-up is scheduled, both in accordance with classification of solid waste. It is divided into three groups, namely compostable organic waste, marketable waste and others. Solid waste treatment at PPST Unand consists of the composting process, then packing and sales to recycle dealers for waste paper, plastic bins, garbage cans and glass bins. The remaining untreated waste as much as $21.23 \%$ is dumped 3 times a week to Air Dingin Landfill Padang. Other non technical programs including organizational system and regulation on $3 R$ participation must also be done.
\end{abstract}

Keyword: Solid waste management, PPST Unand, Composting, Recycling, 3R 


\section{PENDAHULUAN}

Limbah merupakan semua buangan yang dihasilkan oleh aktivitas manusia dan hewan yang berbentuk padat, lumpur (sludge), cair maupun gas yang dibuang karena tidak dibutuhkan atau tidak diinginkan lagi. Walaupun dianggap sudah tidak berguna dan tidak dikehendaki, namun terkadang bahan tersebut masih dapat dimanfaatkan kembali dan dijadikan bahan baku (Damanhuri, 2004).

Damanhuri (2004) mengklasifikasikan limbah berdasarkan fasanya limbah yaitu limbah padat, limbah cair, dan limbah berlumpur (sludge). Limbah padat tersebut berdasarkan SNI 19-2454-2002 kemudian disebut sebagai sampah.

Pengelolaan persampahan sering didefinisikan sebagai kontrol terhadap timbulan sampah mulai dari proses pewadahan, pengumpulan, pemindahan, pengangkutan, pengolahan dan transformasi sampah hingga proses pembuangan akhir. Sistem ini dijalankan dengan penerapan prinsip-prinsip terbaik untuk tujuan kesehatan, ekonomi, keteknikan, konservasi, estetika, lingkungan, dan juga terhadap masyarakat. Keberhasilan pengelolaan sampah bukan hanya tergantung aspek teknis semata, tapi juga mencakup aspek nonteknis, seperti bagaimana mengatur sistem agar dapat berfungsi (Damanhuri, 2004).

Pemahaman yang mendalam mengenai dasar-dasar sistem pengelolaan mutlak dibutuhkan untuk merencanakan suatu sistem pengelolaan sampah. Setidaknya ada 5 aspek penting yang perlu direncanakan pada sistem pengelolaan persampahan di antaranya yaitu aspek teknis operasional, aspek pembiayaan, aspek organisasi/kelembagaan, aspek hukum dan peraturan, serta aspek peran serta masyarakat dan pihak swasta. Kelima aspek tersebut perlu dipahami secara mendalam agar satu dan lainnya saling terkait dan mendukung terciptanya sistem pengelolaan sampah yang sistematis, menyeluruh, dan berkesinambungan sesuai dengan amanat pemerintah dalam UU No. 18 Tahun 2008 tentang Pengelolaan Sampah.
Pemerintah melalui Peraturan Menteri Pekerjaan Umum (Permen PU) Nomor 21/PRT/M/2006 tentang Kebijakan dan Strategi Nasional Pengembangan Sistem Pengelolaan Persampahan (KSNP-SPP), mulai memberlakukan pola penanganan sampah yang berorientasi pada pengurangan dan pemanfaatan sampah. Pada KSNP-SPP pemerintah menargetkan mengurangi kuantitas sampah hingga $20 \%$ melalui beberapa strategi diantaranya peningkatan pemahaman dan penerapan upaya $3 \mathrm{R}$ di skala sumber.

Universitas merupakan salah satu sumber sampah pada sistem persampahan perkotaan. Berkaitan dengan amanat yang diisyaratkan Permen PU No. 21/PRT/M/2006, universitas sebagai salah satu sumber sampah perkotaan sudah sepatutnya memiliki tempat pengolahan sampah terpadu secara mandiri.

Saat ini beberapa kampus di Indonesia mulai berlomba-lomba mengembangkan dan merealisasikan sistem sanitasi dan pengelolaan lingkungan di area kampus yang berorientasi pada pemahaman 3R. Hal ini dimotivasi oleh beberapa hal diantaranya adalah melaksanakan fungsi Universitas sebagai panutan, syarat pemerintah, adanya apresiasi berupa predikat Green Campus dari UI Green Metric Ranking of World Universities.

Saat ini kampus Unand masih menerapkan pola pengelolaan sampah yang berorientasi pada upaya mengumpulkan sampah, mengangkut sampah, dan membuang sampah ke TPA dengan tingkat pelayanan yang baru mencapai $54 \%$ pada tahun 2012 (Slamet dkk, 2013). Sementara itu, konsep pemanfaatan sampah juga belum dilaksanakan sama sekali. Hal ini mengakibatkan masih banyak ditemukannya tumpukan-tumpukan sampah yang tidak terkelola dengan baik di beberapa titik di Kampus Unand yang membuktikan perlu adanya perbaikan sistem persampahan di Kampus Unand.

Menindaklanjuti permasalahan sampah Unand ini dan untuk mendukung terlaksananya konsep 3R secara menyeluruh pada sistem persampahan Kampus Unand, maka disusunlah Perencanaan sistem 3R pengelolaan sampah demi terwujudnya 
Kampus Unand Limau Manis yang berwawasan lingkungan.

\section{METODOLOGI}

Tahapan penelitian dimulai dengan observasi pendahuluan dan proses pengumpulan data. Setelah semua data yang dibutuhkan terkumpul, maka tahapan selanjutnya yang dilakukan adalah analisis data. Setelah itu dilakukanlah perencanaan sistem persampahan sesuai dengan batasan masalah yang telah ditetapkan.

Jenis data yang dikumpulkan berupa data sekunder (diperoleh melalui analisis dokumen penelitian mengenai studi timbulan sampah Kampus Unand serta dokumendokumen pendukung lainnya) dan data primer (yang diperoleh melalui wawancara dan survei lapangan).

Pengumpulan data sekunder dilakukan dengan analisis dokumen dan bertujuan untuk memperoleh data-data mengenai kondisi kawasan kampus, bagaimana persebaran populasi di dalamnya, data-data lain mengenai kondisi persampahan dan pengelolaan persampahan kampus saat ini.

Pengumpulan data primer bertujuan untuk memperoleh pendekatan mengenai pola persebaran populasi dan pola penanganan sampah di kawasan kampus akibat adanya fasilitas perdagang. Selain data terkait fasilitas perdagangan, data primer yang dikumpulkan juga meliputi data kondisi eksisting pola penanganan sampah di kampus yang objek penelitiannya dikonsentrasikan pada Sub Bagian Rumah Tangga Unand sebagai pengelola dan petugas Cleaning Service sebagai operator lapangan sistem kebersihan kampus.

Analisa data yang dilakukan meliputi analisis pola persebaran populasi kampus, analisis kondisi persampahan kampus, serta analisis pola pengelolaan sampah eksisting kampus Unand Limau Manis.

Analisis persebaran populasi kampus penting untuk dilaksanakan karena akan berkaitan dengan persebaran jumlah sampah yang ditimbulkan. Pelaksanaannya yaitu dengan mengelompokkan populasi/penghuni suatu gedung dan membaginya dalam bentuk bilangan persen. Adapun untuk mempermudah dalam pengolahan nantinya maka akan digunakan teknik Data Flow Diagram (DFD) (Santosa dkk., 2008). Dengan teknik ini diharapkan dengan datadata yang ada dapat dihasilkan suatu pendekatan pola persebaran populasi kampus (mahasiswa, pegawai, dosen, dan penduduk pendatang) terhadap gedunggedung kampus.

Aspek-aspek mengenai kondisi persampahan yang dianalisis diantaranya berupa sumbersumber sampah di area kampus, satuan timbulan sampah kampus, komposisi, serta potensi daur ulang sampah kampus. Sumber sampah dianalisis pada masing-masing gedung berdasarkan kegiatan dan fasilitas yang terdapat di dalamnya. Hal ini sesuai dengan penelitian sebelumnya mengenai Studi Timbulan, Komposisi, dan Potensi Daur Ulang Sampah Kampus Universitas Andalas Limau Manis yang dilakukan oleh Chania tahun 2010.

Satuan timbulan sampah, komposisi sampah, serta potensi daur ulang sampah yang terdapat di kawasan Kampus Unand Limau Manis dianalisis berdasarkan studi literatur terhadap penelitian sebelumnya (Chania, 2010; Putri, 2010). Analisis timbulan sampah mengikuti persamaan perhitungan dibawah ini.

$$
\mathbf{Q}_{\mathrm{d}} \quad=\mathbf{P}_{\mathrm{d}} \times \mathbf{q}_{\mathrm{d}}
$$

Dimana, $Q_{d}=$ jumlah timbulan sampah

$$
\begin{aligned}
& \mathrm{P}_{\mathrm{d}}=\text { jumlah populasi } \\
& \mathrm{q}_{\mathrm{d}}=\text { satuan timbulan sampah }
\end{aligned}
$$

Perhitungan proyeksi jumlah timbulan sampah hanya dipengaruhi oleh perubahan jumlah populasi kampus (Putri, 2010) dimana jumlah mahasiswa, tenaga pendidik, dan tenaga kependidikan tersebut mengacu pada Rencana Strategis Unand 2014-2018.

Pola pengelolaan sampah eksisting yang dianalisis diantaranya adalah kelembagaan sistem, sistem pewadahan sampah, sistem pengumpulan sampah, sistem pengolahan sampah, dan sistem pembuangan akhir sampah kampus. Dalam analisis dan evaluasi tersebut dibandingkan kriteria-kriteria yang ada dengan standar yang berlaku untuk sistem pengelolaan sampah yaitu SNI 192454-2002 tentang Tata Cara Teknik Operasional Pengelolaan Sampah Perkotaan, SNI 3242-2008 tentang Pengelolaan Sampah 
di Permukiman serta Permen PU No. 03/PRT/M/2013 tentang Penyelenggaraan Prasarana dan Sarana Persampahan dalam Penanganan Sampah Rumah Tangga dan Sampah Sejenis Sampah Rumah Tangga. Khusus untuk evaluasi aspek kelembagaan sistem pengelolaan sampah di Kampus Unand dilakukan analisis fungsi kelembagaan terkait pelaksana sistem pengelolaan persampahan yang diuraikan di dalam Permendikbud No. 25 Tahun 2012 mengenai Organisasi dan Tata Kerja Unand. Kemudian dibandingkan dengan aspek kelembagaan yang sebaiknya digunakan pada pengelolaan sistem persampahan skala sumber atau kawasan berdasarkan sosialisasi bidang PLP Ditjen Cipta Karya Kementerian PU (Amien, 2011).

Periode perencanaan sistem persampahan mengacu pada Rencana Strategis Unand tahun 2014-2018 yaitu selama 5 tahun. Kemudian untuk memudahkan dalam perencanaan maka dilakukan pendekatan zonasi dimana kawasan Unand dibagi menjadi beberapa zona. Pembagian zona ini dilakukan dengan beberapa pertimbangan di antaranya memanfaatkan pembagian daerah pelayanan yang telah ada pada kondisi eksisting sistem pengelolaan sampah Kampus Unand Limau Manis, jumlah timbulan, batas jalan, atau kesamaan topografi daerah. Setelah itu dilanjutkan dengan perencanaan sistem persampahan.

\section{HASIL DAN PEMBAHASAN}

\section{Evaluasi Sistem Persampahan Eksisting}

Gambar 1 menunjukkan proyeksi jumlah timbulan sampah Kampus Unand Limau Manis dari tahun 2014-2018.

Saat ini Kampus Unand Limau Manis memiliki 5 unit kontainer $6 \mathrm{~m}^{3}$ yang diangkut 1 kali seminggu oleh DKP Kota Padang. Hal ini berarti total sampah yang diangkut ke TPA setiap minggunya adalah $30 \mathrm{~m}^{3}$ atau 4,286 $\mathrm{m}^{3} /$ hari. Timbulan kampus Unand pada tahun 2014 adalah 21,152 $\mathrm{m}^{3} /$ hari. Dengan membandingkan jumlah sampah yang terangkut ke TPA dengan total timbulan sampah yang ada maka tingkat pelayanan masih sangat rendah yaitu $20,3 \%$. Gambar 2 menunjukkan bagan perbandingan jumlah sampah yang terangkut ke TPA dan jumlah sampah yang tidak terkelola

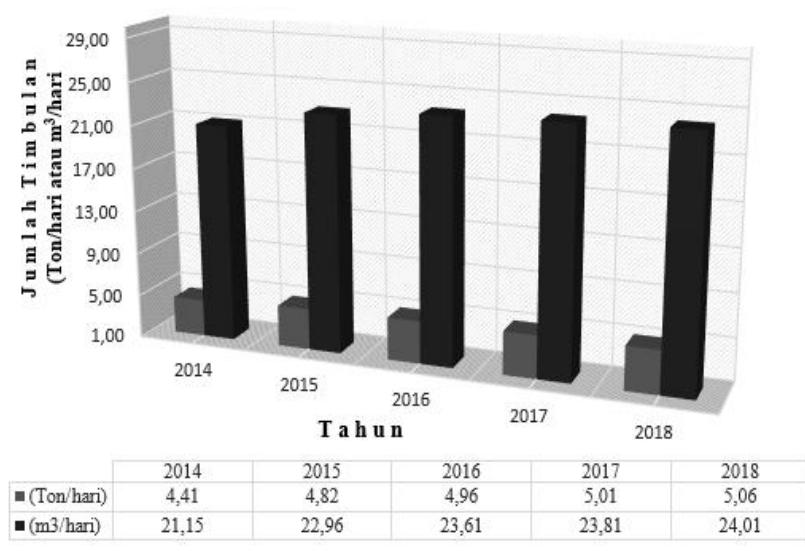

\section{Gambar 1 Proyeksi Jumlah Timbulan Sampah Unand 2014-2018}

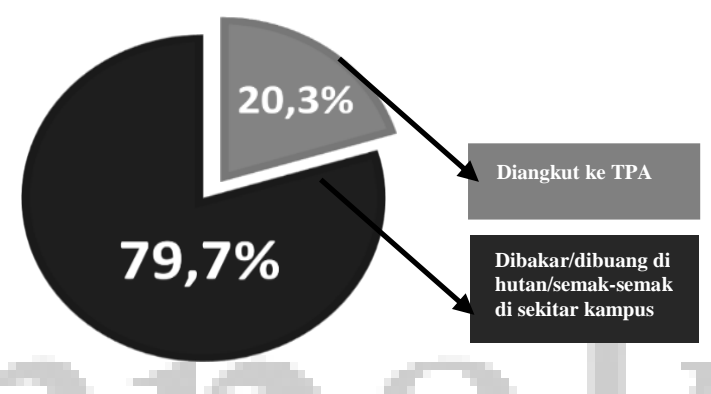

Gambar 2 Tingkat Pelayanan Sistem Persampahan Kampus

Berdasarkan gambar 2 di atas, sekitar 79,7 \% sampah di kawasan Unand diperkirakan dibuang dan dibakar di beberapa lokasi di area kampus. Berdasarkan hasil observasi lapangan diketahui bahwa terdapat \pm 37 titik pembuangan dan pembakaran sampah yang dilakukan secara terbuka. Adanya titik pembuangan dan pembakaran sampah pada suatu area menunjukkan bahwa area tersebut tidak memperoleh pelayanan yang baik pada sistem persampahannya. Bahkan berdasarkan perundang-undangan persampahan (UU 18-2008) praktik pembakaran sampah secara sembarangan secara tegas telah dilarang pelaksanaannya oleh pemerintah.

Berdasarkan Kebijakan dan Strategi Nasional Pengembangan Sistem Pengelolaan Persampahan (Permen PU No. 21/PRT/M/2006) pengurangan sampah di sumber melalui strategi $3 \mathrm{R}$ ditargetkan dapat mencapai $20 \%$. Target pengurangan sampah ini belum dipenuhi oleh Unand karena tingkat pelayanan sistem persampahan 
sebesar 20,3 \% tersebut hanya tercapai melalui upaya pembuangan sampah ke TPA.

\section{Rencana Sistem Persampahan Kampus Aspek Teknis}

Berikut merupakan beberapa konsep 3R yang dapat diterapkan oleh seluruh warga Kampus Unand Limau Manis. Konsep ini disusun berdasarkan pedoman umum 3R di permukiman (Amien, 2011) yang disesuaikan dengan kondisi Unand.

1. Reduce, yaitu meminimasi sampah yang hendaknya dilakukan sejak sampah belum terbentuk yaitu dengan menghemat penggunaan bahan, membatasi konsumsi sesuai dengan kebutuhan, memilih bahan yang mengandung sedikit sampah, atau pengumpulan tugas mahasiswa dengan email atau dalam bentuk file komputer (softcopy);

2. Reuse, yaitu upaya pemanfaatan sampah yang dapat dilakukan dengan menggunakan kembali sampah sesuai fungsinya sebelum dibuang seperti misalnya menggunakan kertas bolakbalik untuk kegiatan bimbingan bagi mahasiswa praktikum, tugas besar, atau skripsi yang membutuhkan perbaikan laporan yang berulang-ulang;

3. Recycle, mendaur ulang sampah dengan pengomposan dan menjual kembali sampah yang bernilai ekonomi. Untuk melaksanakan ini, Unand harus membangun manajemen pengelolaan sampah dari sumber secara terpilah.

Sesuai dengan Permen PU 21/PRT/M/2006 tentang kebijakan dan strategi Nasional Pengembangan Sistem Pengelolaan Persampahan, diperlukan suatu perubahan paradigma pengelolaan sampah kampus yang berorientasi pada pembuangan sampah ke TPA menjadi lebih mengedepankan proses pengelolaan sampah yang ramah lingkungan, yaitu dengan melakukan upaya pengurangan dan pemanfaatan sampah sebelum akhirnya sampah dibuang ke TPA (target $20 \%$ pada tahun 2014).

Berdasarkan komposisi dan potensi daur ulang sampah, Gambar 3 menunjukkan konsep sekaligus mass balance sistem 3R berwawasan lingkungan.

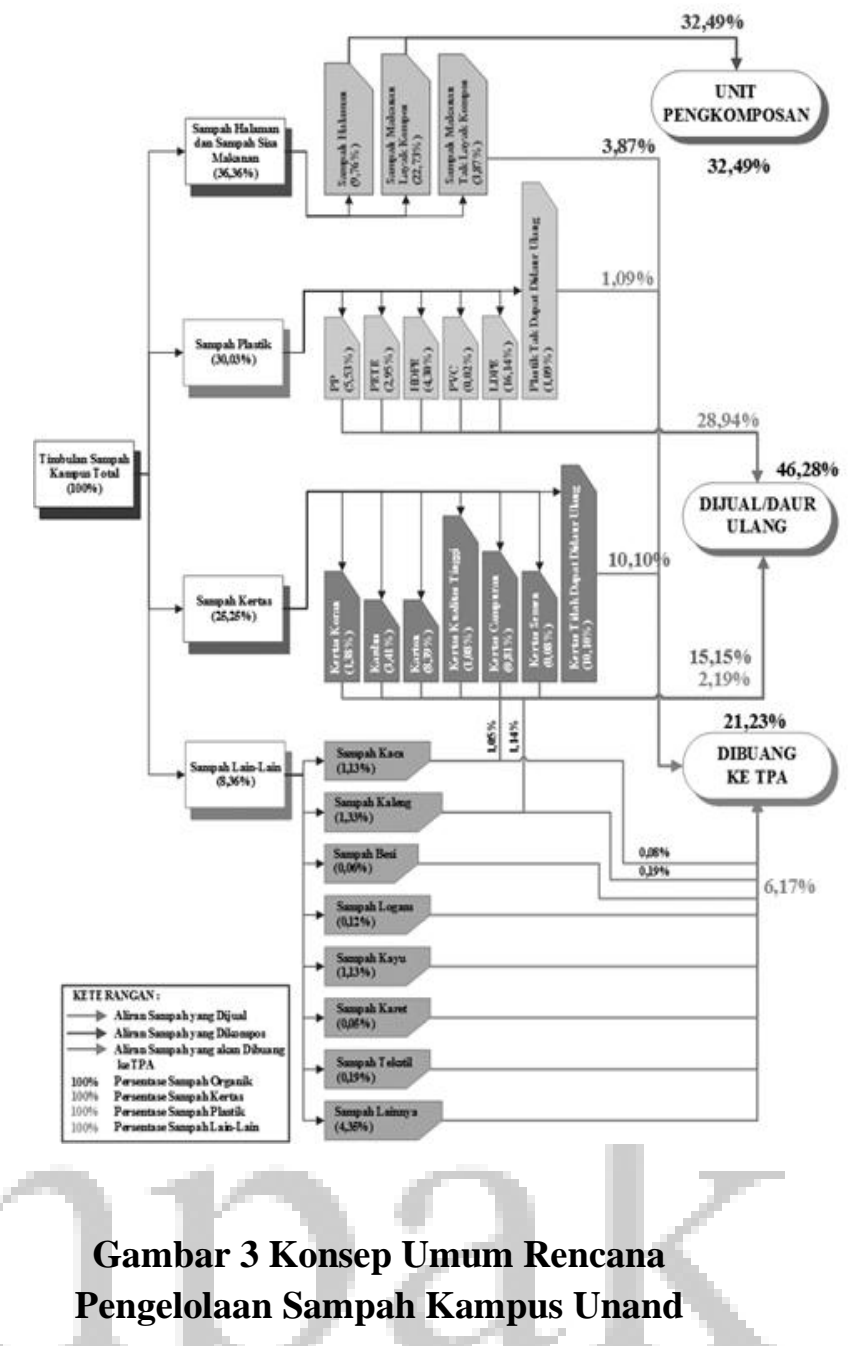

Berdasarkan - konsep umum pengelolaan sampah Kampus Unand tersebut tampak bahwa direncanakan $100 \%$ sampah dapat diangkut dari sumbernya, dimana 78,77 \% dapat dimanfaatkan di Pusat Pengolahan Sampah Terpadu (PPST) sehingga jumlah sampah yang dibuang ke TPA dapat diminimalkan hingga $21,23 \%$.

Perancangan rute dan jadwal pengumpulan dan pengangkutan sampah juga dilakukan untuk meningkatkan pelayanan terhadap sistem pengumpulan dan pengangkutan sampah dari seluruh daerah pelayanan menuju PPST Unand sebagai tempat pengolahan seluruh sampah yang dihasilkan sebelum akhirnya dibuang ke TPA.

\section{Sistem Pewadahan Sampah}

Berdasarkan teknik pengolahan yang ada di PPST Unand yaitu pengomposan dan penjualan sampah yang bernilai ekonomi, maka sistem pewadahan yang akan 
diterapkan adalah pewadahan sistem terpilah dengan jenis pemilahan sebanyak 3 kategori yaitu wadah untuk sampah organik yang dapat dikompos, wadah untuk yang dapat dijual seperti sampah kertas, botol plastik, gelas plastik, karton, kaleng minuman, dsb dan wadah sampah lain-lain yang tidak dapat dikompos maupun di daur ulang yang akan dibuang ke TPA Air Dingin. Agar memudahkan bagi warga kampus dalam melakukan pembuangan sampah secara terpilah, maka pewadahan diberi warna yang berbeda yaitu hijau untuk sampah yang bisa dikompos, biru untuk sampah yang bisa di jual, dan abu-abu untuk sampah lain-lain. Tiap bin sampah juga dilengkapi dengan gambar-gambar jenis sampah yang sesuai agar lebih informatif.

Pola pewadahan yang akan digunakan direncanakan berupa pola individual dan pola komunal. Wadah yang digunakan kemudian disebut sebagai wadah individual dan wadah komunal. Wadah individual merupakan wadah sampah yang diletakkan di beberapa lokasi di dalam gedung yang berdekatan dengan fasilitas-fasilitas gedung dimana sampah dihasilkan. Wadah sampah ini dapat digunakan oleh semua populasi yang berada di dalam area gedung tersebut. Lama waktu penyimpanan sampah di dalam wadah ini akan direncanakan selama satu hari untuk kemudian dikumpulkan oleh petugas kebersihan gedung di wadah komunal. Kemudian wadah komunal merupakan wadah sampah yang diletakkan pada titik tertentu di gedung yang bersangkutan yang dapat diakses oleh petugas pengumpulan sampah nantinya. Wadah sampah ini akan digunakan oleh petugas kebersihan gedung untuk menyimpan sampah dari wadah-wadah individual dan wadah jalan yang ada di sekitar di gedung tersebut sebelum petugas pengumpul sampah menjemput sampah sesuai jadwal yang ditentukan (penjadwalan dibahas pada subbab berikutnya). Lamanya penyimpanan sampah di wadah komunal disesuaikan dengan jenis sampahnya. Berdasarkan Lampiran II Permen PU No. 03/PRT/M/2013 lamanya penyimpanan sampah organik maksimal adalah selama 2 hari sedangkan untuk sampah guna ulang (kertas dan plastik) dan sampah lainnya dapat disimpan hingga lebih dari 3 hari.
Adapun wadah yang digunakan dibedakan berdasarkan peruntukan wadah yaitu bin dari bahan plastik bervolume $50 \mathrm{~L}$ digunakan sebagai wadah sampah untuk gedung. Kemudian bin dari bahan fiberglas dan memiliki volume $30 \mathrm{~L}$ digunakan sebagai wadah sampah untuk jalan. Serta wadah sampah dari bahan plastik bervolume $120 \mathrm{~L}$ digunakan untuk wadah komunal gedung dan wadah di fasilitas fasilitas komersil

Wadah sampah komunal (bin 120 L) perlu diatur lokasi perletakannya karena berkaitan dengan kelancaran sistem pengumpulan sampah oleh petugas pengumpul nantinya. Berdasarkan isyarat Lampiran II Permen PU No. 03/PRT/M/2013 wadah sampah yang akan dikumpulkan diusahakan diletakkan di tempat yang dapat dijangkau oleh kendaraan pengangkut sampah seperti misalnya dapat diletakkan di depan atau belakang pekarangan bangunan. Selain itu yang mesti diperhatikan adalah bahwa wadah sampah komunal tidak boleh diletakkan di tepi jalan utama dan/atau tidak mengambil lahan trotoar. Lokasi perletakan tersebut tidak boleh mengganggu pemakai bangunan atau fasilitas dimana sampah dihasilkan. Titik perletakan wadah komunal nantinya direncanakan sebagai lokasi penjemputan sampah. Pada kondisi tertentu khusus untuk sampah hasil penyapuan jalan atau pun sampah taman dapat dimasukkan ke dalam plastik dan diletakkan di tepi jalan yang dapat diakses kendaraan pengangkut sampah. Rencana lokasi yang dijadikan sebagai titik perletakan bin komunal $120 \mathrm{~L}$ dapat dilihat pada Tabel 1.

\section{Sistem Pengumpulan dan Pengangkutan Sampah}

Pengumpulan sampah dilakukan secara terpilah dengan pembedaan jadwal pengumpulan sampah. Penentuan jadwal pengangkutan sampah memperhatikan batas waktu penyimpanan sampah berdasarkan jenisnya, kapasitas wadah komunal, kapasitas dan jumlah ritasi maksimum kendaraan dalam 1 hari. Direncanakan wadah sampah yang dirancang mampu menampung sampah organik, kertas, plastik dan sampah lain-lain tetap berada di area selama masing-masing adalah 2 hari untuk 
sampah organik yang bisa dikompos, 3 dan 7 hari untuk sampah lainnya.

Tabel 1 Lokasi Wadah Komunal

\begin{tabular}{|c|c|c|}
\hline Zona & $\begin{array}{l}\text { Nomor Wadah } \\
\text { Komunal }\end{array}$ & Lokasi Wadah \\
\hline \multirow{8}{*}{ A } & A0 & $\begin{array}{l}\text { Jalan Utama Gerbang - Pos } \\
\text { Satpam } 2 \text { Depan PKM }\end{array}$ \\
\hline & $\mathrm{A} 1$ & Gedung PKM \\
\hline & $\mathrm{A} 2$ & Gedung Asrama RPX/SURF \\
\hline & A3 & Gedung Asrama Hijau \\
\hline & A4 & Gedung Asrama Orange \\
\hline & A5 & Gedung Business Center \\
\hline & A6 & Gedung Asrama M.Syaf-Roesma \\
\hline & A7 & Gedung Asrama PU \\
\hline \multirow{3}{*}{ B } & B1 & Mesjid Nurul Ilmi \\
\hline & $\mathrm{B} 2$ & Convention Hall \\
\hline & B3 & $\begin{array}{l}\text { Gedung Pusat Bahasa dan Bank } \\
\text { Center }\end{array}$ \\
\hline \multirow{3}{*}{$\mathrm{C}$} & $\mathrm{C} 1$ & Program Studi Ilmu Keperawatan \\
\hline & $\mathrm{C} 2$ & Fakultas Kedokteran \\
\hline & $\mathrm{C} 3$ & Rumah Sakit Pendidikan Unand \\
\hline \multirow{2}{*}{$\mathrm{D}$} & D1 & \multirow{2}{*}{ Fakultas Ekonomi } \\
\hline & D2 & \\
\hline \multirow{2}{*}{$\mathrm{E}$} & E1 & Gedung Rektorat \\
\hline & E2 & Gedung Auditorium \\
\hline \multirow{4}{*}{$\mathrm{F}$} & F1 & Gedung DIII Ekonomi \\
\hline & $\mathrm{F} 2$ & Fakultas Hukum \\
\hline & F3 & Fakultas FISIP \\
\hline & $\mathrm{F} 4$ & Fakultas Ilmu Budaya \\
\hline \multirow{3}{*}{$\mathrm{G}$} & G1 & \multirow{3}{*}{ Fakultas Peternakan } \\
\hline & $\mathrm{G} 2$ & \\
\hline & G3 & \\
\hline \multirow{3}{*}{$\mathrm{H}$} & $\mathrm{H} 1$ & Gedung Perpustakaan Pusat \\
\hline & $\mathrm{H} 2$ & Gedung A \\
\hline & $\mathrm{H} 3$ & Kantin A-F \\
\hline \multirow{3}{*}{ I } & I1 & Gedung F \\
\hline & $\mathrm{I} 2$ & Fakultas Teknik Informatika \\
\hline & $\mathrm{I} 3$ & Gedung E \\
\hline \multirow{2}{*}{$\mathrm{J}$} & J1 & \multirow{2}{*}{$\begin{array}{l}\text { Fakultas Pertanian dan Teknologi } \\
\text { Pertanian }\end{array}$} \\
\hline & $\mathrm{J} 2$ & \\
\hline \multirow{6}{*}{$\mathrm{K}$} & $\mathrm{K} 1$ & \multirow{4}{*}{ Fakultas MIPA } \\
\hline & $\mathrm{K} 2$ & \\
\hline & $\mathrm{K} 3$ & \\
\hline & K4 & \\
\hline & K5 & $\begin{array}{l}\text { Gedung Laboratorium Biota } \\
\text { Sumatera }\end{array}$ \\
\hline & K6 & Gedung Olahraga Futsal \\
\hline \multirow{6}{*}{$\mathrm{L}$} & L1 & Gedung I \\
\hline & L2 & Laboratorium Dasar dan Central \\
\hline & L3 & Gedung D \\
\hline & L4 & Gedung $\mathrm{G}$ \\
\hline & L5 & Gedung H \\
\hline & L6 & KOPMA \\
\hline \multirow{3}{*}{ M } & M1 & Gedung Pasca Sarjana \\
\hline & M2 & Fakultas Farmasi baru \\
\hline & M3 & Pool bus Kampus \\
\hline \multirow{4}{*}{$\mathrm{N}$} & N1 & \multirow{4}{*}{ Fakultas Teknik } \\
\hline & $\mathrm{N} 2$ & \\
\hline & N3 & \\
\hline & N4 & \\
\hline
\end{tabular}

Direncanakan sampah organik yang bisa dikompos akan dijemput setiap 2 hari sekali yaitu pada setiap hari Senin, Rabu, dan Jumat. Sampah yang bernilai ekonomi dijemput setiap 3 hari sekali yaitu setiap hari Selasa dan Jumat. Sedangkan sampah lainlain akan dijemput setiap 7 hari sekali yaitu pada hari Sabtu.

Adapun rute pengumpulan sampah kampus dibagi menjadi 3 rute yaitu Rute A, Rute B, dan Rute C. Rute A akan melayani pengangkutan sampah di utara kampus (K3K4-K6-K5-K2-K1-J2-G3-G2-G1-D2-A1-

D1-E1-J1-L6-L5) dan Rute B akan melayani pengangkutan sampah di selatan area kampus (L1-L2-H1-H2-H3-E2-A0-B2-F4M1-M3-C1-B3). Sedangkan bagian tengah kampus akan dilayani pengangkutan sampahnya melalui adanya rute C (L3-M2I1-I2-I3-F3-F1-F2-C2-C3-B1-A3-A4-A5-

A6-A7-A2-L4-N4-N3-N2-N1).

\section{Sistem Pengolahan Sampah}

Berdasarkan komposisi sampah Kampus Unand maka pengolahan yang dirancang pada lokasi PPST Unand ini adalah proses pemilahan, pencucian, pengepakan dan penjualan untuk sampah yang layak jual dan proses pengomposan untuk sampah organik yang dapat dikompos. Sampah yang layak jual meliputi berbagai botol plastik, berbagai gelas plastik, berbagai kertas, karton, kaleng minuman hingga logam. Kategori sampah lain-lain tidak masuk ke PPST, melainkan dibuang ke kontainer DKP untuk dibawa ke TPA Air Dingin. Adapun sisa sampah yang tidak dapat dijual dan dikompos dibuang ke TPA Air Dingin Kota Padang.

Untuk melaksanakan fungsinya, PPST direncanakan memiliki ruang-ruang sebagai berikut:

1. Ruang penimbangan sampah;

2. Ruang pencurahan sampah organik;

3. Ruang pencacahan sampah organik;

4. Ruang pengomposan;

5. Ruang peningkatan kualitas dan pengemasan kompos;

6. Gudang penyimpanan kompos jadi;

7. Ruang pencurahan, dan pengepakan sampah kertas;

8. Ruang pencurahan sampah plastik;

9. Ruang pencucian dan pengemasan plastik daur ulang;

10. Ruang pencurahan dan pemilahan sampah lain-lain;

11. Ruang pencucian dan pengemasan kaleng dan kaca daur ulang;

12. Gudang penyimpanan sampah kering (kertas, plastik, kaca, dan kaleng daur ulang);

13. Lahan penampungan residu yang akan dibuang; 
14. Ruang kantor/pos jaga

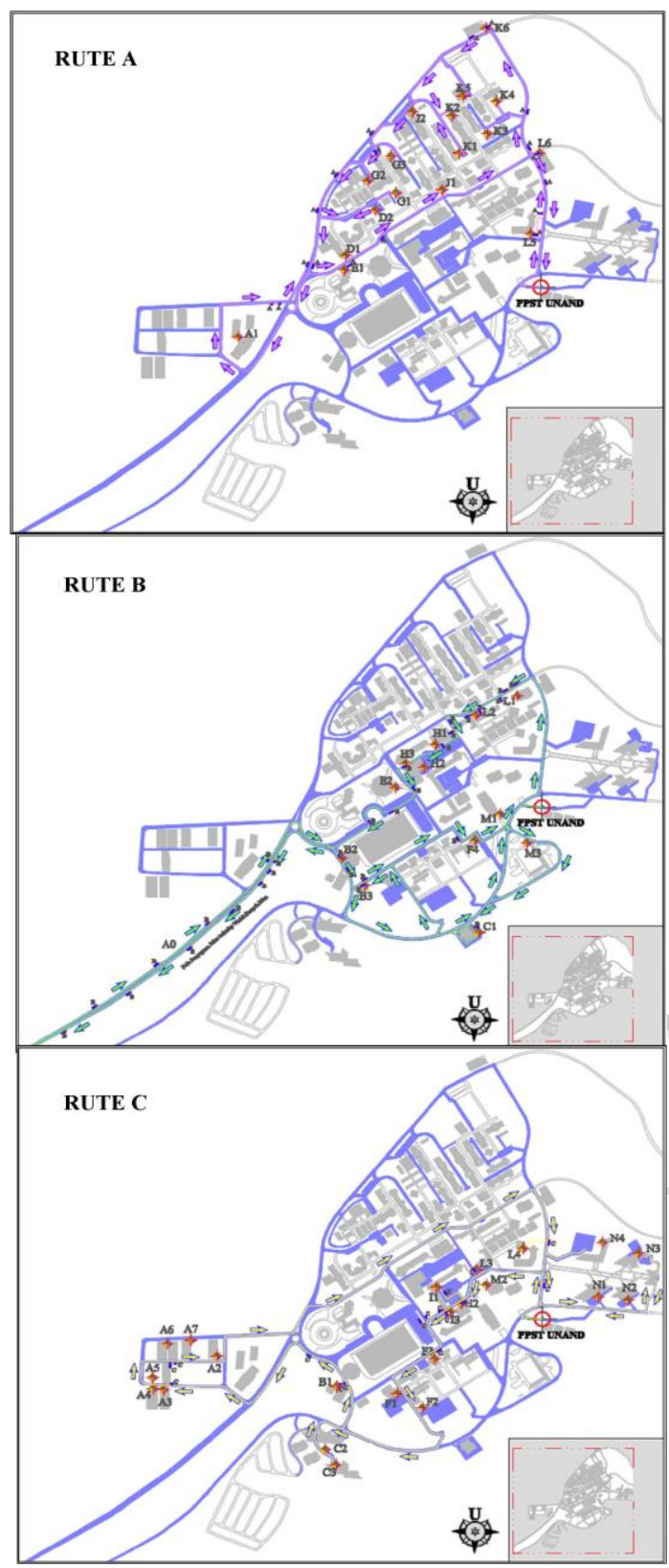

Gambar 4 Rute Pengumpulan Sampah

Berdasarkan rencana operasional PPST, kegiatan di PPST akan dilaksanakan dari pukul 7.00 hingga pukul 16.00 .

\section{Rencana Sistem Persampahan Kampus Aspek Non Teknis}

Rencana aspek teknis yang telah disusun sedemikian rupa tidak akan bisa terlaksana jika tidak dibantu dengan penerapan rencana aspek non teknis. Aspek non teknis meliputi sistem kelembagaan, peraturan dan peran serta masyarakat.
Aspek kelembagaan yang harus dipenuhi meliputi:

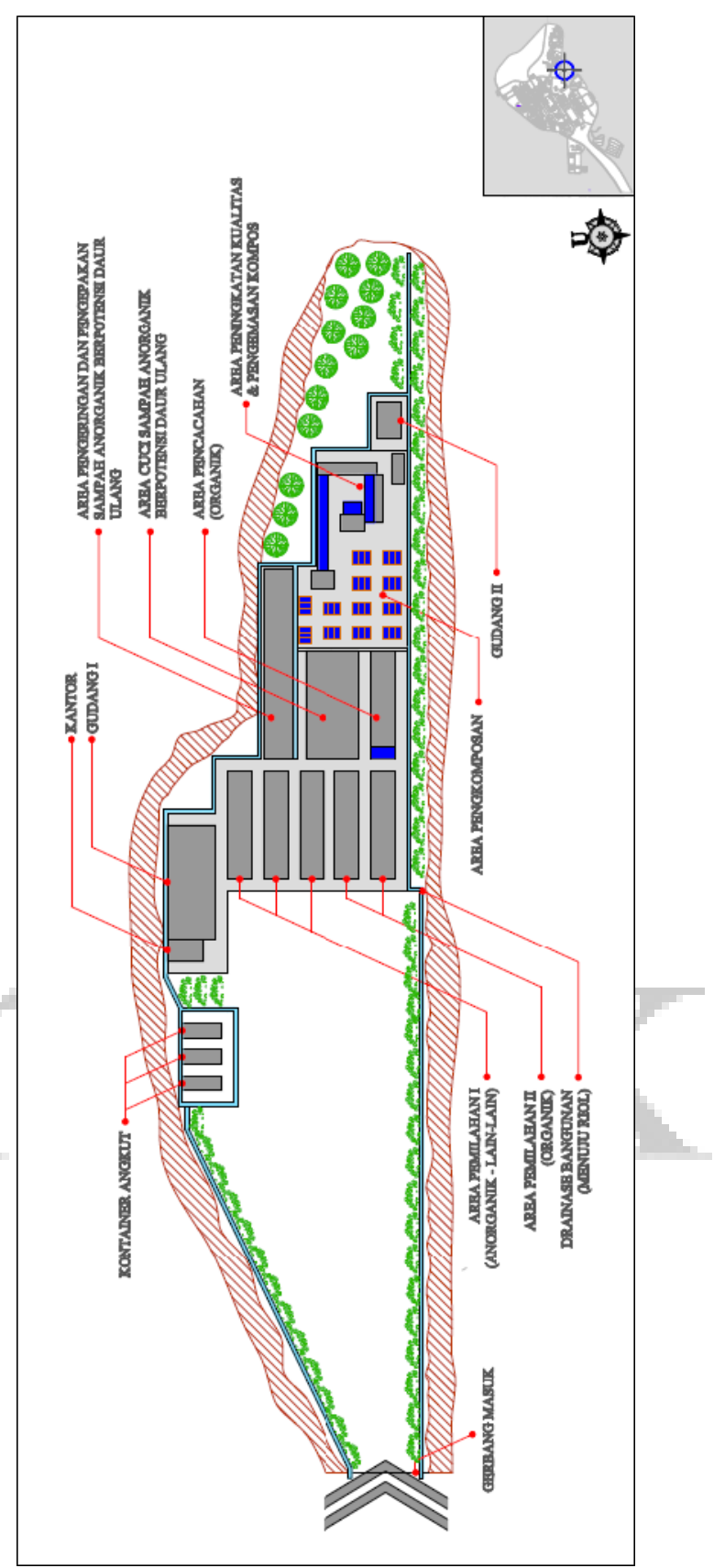

Gambar 5 Lay Out PPST Unand

Unand membentuk suatu unit pelayanan teknis (UPT) tingkat universitas yang khusus melaksanakan manajemen persampahan. Unit ini harus:

[1]. memiliki personil yang memadai dan pendanaan reguler yang cukup.

[2]. Unit ini memiliki koordinasi langsung dengan pimpinan di Fakultas, misalnya dengan Wakil Dekan 2.

Aspek peraturan dan peran serta masyarakat yang harus dipenuhi adalah: 
1. Unand membuat peraturan pelaksanaan tentang pengelolaan sampah di Universitas Andalas, yang berisi prosedur, tugas dan tanggung jawab, mekanisme pengawasan dan evaluasi dan mekanisme reward dan punishment bagi warga kampus.

2. Memberikan sosialisasi tentang pengelolaan sampah terpadu kepada seluruh warga kampus.

3. Membuat surat edaran secara terbuka tentang kewajiban warga kampus dalam membantu pengelolaan sampah.

4. Menyertakan kewajiban memilah sampah menjadi 3 jenis dalam kontrakkontrak penyewaan fasilitas komersial di Unand.

5. Membentuk kerjasama dengan bandar/lapak/industri yang akan membeli sampah bernilai jual dari PPST Unand.

\section{SIMPULAN}

Sistem pengelolaan persampahan kampus yang dirancang terdiri dari 3 subsistem yaitu sistem pewadahan, sistem pengumpulan dan transportasi, serta Pusat Pengelolaan Sampah Terpadu (PPST).

Rencana tingkat pelayanan sistem pewadahan dan pengumpulan/ pengangkutan sampah kampus adalah $100 \%$ dan tingkat pengolahan di PPST Unand mencapai $78,77 \%$ sampah.

Sistem pewadahan sampah yang dirancang adalah sistem terpilah yang dilakukan dengan pembedaan warna wadah sampah dilengkapi dengan gambar-gambar jenis sampah agar lebih informatif;

Jenis sampah organik yang bisa dikompos diangkut menuju fasilitas pengomposan PPST, sampah yang bernilai jual diangkut menuju fasilitas daur ulang PPST, dan sampah lain-lain diangkut menuju kontainer TPA.

Untuk dapat melaksanakan operasi PPST secara institusional, profesional dan terpadu, Unand perlu membentuk UPT (unit pelayanan teknis).

Perlu adanya peraturan rektor tentang pelaksanaan pengelolaan sampah secara terpadu.
Sosialisasi kepada warga kampus tentang pengelolaan sampah perlu dilakukan secara intensif dan terus menerus.

\section{DAFTAR PUSTAKA}

Amien, M, S., dkk. 2011. Materi Diseminasi Keteknikan Bidang Persampahan. http://www.sanitasi.or.id/ppsp/2012/01/ 27/materi-diseminasi-keteknikanbidang-persampahan/. Diunduh pada tanggal 17 Desember 2013.

Chania, V. 2010. Studi Timbulan, Komposisi, dan Potensi Daur Ulang Sampah Kampus Universitas Andalas Limau Manis. Tugas Akhir Jurusan Teknik Lingkungan. Unand. Padang.

Damanhuri, E. 2004. Diktat Pengelolaan Sampah. Bandung: Penerbit TL ITB.

Peraturan Menteri Pekerjaan Umum Nomor: 03/PRT/M/2013 tentang Penyelenggaraan Prasarana dan Sarana Persampahan dalam Penanganan Sampah Rumah Tangga dan Sampah Sejenis Sampah Rumah Tangga.

Peraturan Menteri Pekerjaan Umum Nomor: 21/PRT/M/2006 tentang Kebijakan dan Strategi Nasional Pengembangan Sistem Pengelolaan Persampahan (KSNP-SPP).

Peraturan Menteri Pendidikan dan Kebudayaan Republik Indonesia Nomor 25 Tahun 2012 tentang Organisasi dan Tata Kerja Universitas Andalas.

Putri, A. A. 2010. Pengembangan Sistem Pengolahan Persampahan Kampus Unand Limau Manis. Tugas Akhir Jurusan Teknik Lingkungan. Unand. Padang.

Santosa, B., Sofyan, H., dan Widiyastuti, W. A., 2008. Sistem Informasi Geografis Penyebaran Penduduk Berdasarkan Tingkat Usia di Kabupaten Sleman Berbasis Web. Volume 1979-2328.

Slamet, R., Yenni, R., dan Rizki, A., 2013. Studi Pemanfaatan Sampah Di Universitas Andalas. Vol.10 (1) : 77-82. SNI 19-2454-2002 tentang Tata Cara Teknik Operasional Sampah Perkotaan.

SNI 3242-2008 tentang Pengelolaan Sampah di Permukiman.

Undang-Undang Nomor 18 Tahun 2008 tentang Pengelolaan Sampah. 